\title{
AHL-lactonase characteristics of Bacillus thuringiensis SGT3g and its effectiveness in inhibiting pathogenicity of Dickeya dadantii
}

\author{
Putri Eka Sari $^{1}$, Iman $\underline{\text { Rusmana }}^{1 \star}$ and Alina $\underline{\text { Akhdiya }}^{2}$ \\ ${ }^{1}$ Department of Biology, Faculty of Mathematics and Natural Science, Bogor Agricultural University, Kampus IPB \\ Dramaga, Bogor 16680, West Java, Indonesia. \\ ${ }^{2}$ Indonesian Center for Agricultural Biotechnology \& Genetic Resources Research \& Development, Cimanggu, Bogor, \\ West Java, Indonesia. \\ Email: irusmana@ipb.ac.id
}

Received 28 February 2016; Received in revised form 16 May 2016; Accepted 22 July 2016

\begin{abstract}
Aims: Dickeya dadantii is a pathogenic bacterium causing bacterial soft rot disease in plants. The bacterium uses a homoserine lactone signal in its quorum sensing process to express the virulence factor genes. Anti-quorum sensing is a new approach to control plant pathogenic bacteria. The aims of this study are to characterize AHL-lactonase enzyme produced by Bacillus thuringiensis SGT3g and to determine its effectiveness in inhibiting virulence of $D$. dadantii.

Methodology and results: Activity of AHL-lactonase was determined using Chromobacterium violaceum as a bacterial biosensor. The crude extract enzymes of AHL-lactonase on both as extracellular and intracellular enzymes were analyzed their enzyme activity of protein precipitation and dialysis products. The optimum activity of AHL-lactonase was found at $30^{\circ} \mathrm{C}$ and $\mathrm{pH} 5-8$. Bacillus thuringiensis SGT3g was capable to reduce soft rot symptom disease caused by $D$. dadantii on Phalaenopsis orchid leaves after $24 \mathrm{~h}$ of incubation.

Conclusion, significance and impact study: Bacillus thuringiensis SGT3g was capable to degrade AHL signal of $C$. violaceum and $D$. dadantii. The activity $A H L$-lactonase of $B$. thuringiensis SGT3g had a wide range of $\mathrm{pH}$ and temperature. The lactonase could reduce soft rot symptom disease caused by $D$. dadantii without any growth inhibition of $D$. dadantii on orchid leaves. Bacillus thuringiensis SGT3g can be used as an alternative biopesticide to control phytopathogenic bacteria due to its capability to suppress bacterial pathogenic virulence.
\end{abstract}

Keywords: AHL-degradation, Bacillus thuringiensis, Phalaenopsis, quorum sensing, quorum quenching

\section{INTRODUCTION}

Communication mechanisms among bacterial cells are known as quorum sensing (QS). This mechanism involves an auto-inducer as a signal molecule. During the quorum sensing process, auto-inducers are secreted onto environment then accumulated, being recognized and reentering the cells of the bacteria (Czajkowski and Jafra, 2009; Sakr et al., 2013). In certain concentration, autoinducers will form a complex with transcription-activating regulatory proteins and eventually control genes expression of biofilm formation, virulence factors, bioluminescent, and antibiotics production. In general, QS is a gene expression regulation that depends on the number of bacterial population and auto-inducers accumulation (Dong et al., 2007).

Plant pathogenic bacteria use the QS process to activate their virulence factors. Phytopathogenic bacteria such as Dickeya dadantii or Erwinia chrysanthemi use Nacyl homoserine lactone ( $A H L)$ signal to control gene expression of their virulence factors. The AHL signal has a significant role in virulence factor process of $D$. dadantii to produce Plant Cell-Wall Degrading Enzyme (CWDE), i.e pectinase and cellulase (Barnard et al., 2007; Muharram et al., 2012). Activity of the pectinolytic and cellulolitic enzymes is to degrade plant cell wall (Dong et al., 2000; Samson et al., 2005; Barnard et al., 2007). This bacterium causes soft rot diseases in orchids, cabbages, and carrots (McMillan et al., 2007; Muharram et al., 2012).

Process of QS can be controlled in various ways, including: inhibiting $\mathrm{AHL}$ biosynthesis, destroying QS signal molecules through the activities of $\mathrm{AHL}$-lactonases and $\mathrm{AHL}$-acylaces, the inhibition of $\mathrm{AHL}$ efflux proteins, inhibition of transcriptional activators (LuxR homologs) and the use of QS analogs (Kalia et al., 2015). Destroying QS signal through the activities of AHL-lactonases can inhibit accumulation of $\mathrm{AHL}$ signals surrounding the bacterial cells (Chen et al., 2013; Ghani et al., 2014; Kalia et al., 2015). AHL-lactonase hydrolyzes the lactone ring of $\mathrm{N}$-(pentanoyl) homoserine lactone (C5HSL), $\mathrm{N}$-(decanoyl) homoserine (C10HSL), and a few synthetic compounds [ $N$-tert-butyloxycarbonil)-DL-homoserine lactone and $N$ (benzyloxycarbonyl)-L-homoserine lactone] with high efficiency (Kumar et al., 2013). As a result, the enzyme 
can inhibit genes expression of virulence factor without any effect to the growth of the pathogenic bacteria. Thus it can avoid the selection pressure that can generate bacterial resistant mechanisms of the pathogenic bacteria (Dong et al., 2004; Choudhary and Dannert, 2010).

AHL-lactonase was initially found in Bacillus sp. 240B1 by Dong et al. (2001) which is capable to reduce soft rot disease caused by $E$. carotovora in potato plants. Bacteria from various genera which are capable to degrade $\mathrm{AHL}$ are Bacillus sp., $B$. thuringiensis, Arthrobacter sp., and Rhodococcus sp. (Dong et al., 2002; Park et al., 2003; Wang et al., 2004; Park et al., 2006). The activity of AHL-lactonase is affected by several factors, such as temperature, $\mathrm{pH}$, and divalent ions. AHL-lactonase of $B$. weihenstephanensis has the optimum activity at $50{ }^{\circ} \mathrm{C}$ and $\mathrm{pH}$ range of $6-9$, it is also unaffected by divalent ions i.e. $\mathrm{Ca}^{2+}, \mathrm{Mg}^{2+}$, and $\mathrm{Fe}^{2+}(\mathrm{Sakr}$ et al., 2013).

Afiah (2011) isolated $B$. thuringiensis SGT3g producing $\mathrm{AHL}$-lactonase. $\mathrm{AHI}$-lactonase characterization of $B$. thuringiensis SGT3g is necessary in order to determine the enzyme activity and stability against $\mathrm{pH}$ and temperature. Therefore, in this study we describe the characteristics of $\mathrm{AHL}$-lactonase of $B$. thuringiensis SGT3g AHL-lactonase, and its effectiveness in inhibiting the virulence of phytopathogenic bacterium $D$. dadantii.

\section{MATERIALS AND METHODS}

\section{Crude enzyme extraction}

Bacillus thuringiensis SGT3g isolated from agriculture land at Java Island, Indonesia (Afiah, 2011), was grown on Nutrient Agar medium. A total of $2 \mathrm{~mL}$ of $B$. thuringiensis SGT3g culture with OD of 0.6-0.8 was inoculated into $200 \mathrm{~mL}$ LB media. Incubation was done on a shaker incubator at $150 \mathrm{rpm}$ and at room temperature for $9 \mathrm{~h}$. The culture was centrifuged at 9800 $\times g$, to obtain supernatant as an extracellular crude enzyme; and the cell pellet as source of intracellular crude enzyme. To obtain intracellular crude enzyme, cell pellet was washed using Phosphate Saline Buffer (PBS) pH 7.4 and then centrifuged at $4{ }^{\circ} \mathrm{C}$ and $6000 \mathrm{rpm}$ for $10 \mathrm{~min}$. After pellet re-suspension using PBS, the cells was lysed using sonicator for 2 min in 5 times replications. The cell debris was separated by centrifugation at $12500 \times g$ for 15 min and the supernatant was collected as intracellular crude enzyme (Dong et al., 2002; Cao et al., 2012).

\section{Bioassay of AHL degrading activity}

Activity of $\mathrm{AHL}$-lactonase was determined using disc diffusion assay (Fitriyah et al., 2014). A total of $80 \mu \mathrm{L}$ crude extract enzyme was dropped on a paper disc and placed on a plate of semi-solid Luria-Bertani Agar (LBA) media that had been inoculated with $1 \%$ culture of $C$. violaceum $\left(10^{8} \mathrm{CFU} / \mathrm{mL}\right)$. The plate was then incubated at room temperature for $24 \mathrm{~h}$. AHL degradation activity was determined by measuring the diameter of a non-purple zone surrounding the paper disc.

\section{Enzyme purification and characterization}

AHL-lactonase was precipitated using ammonium sulphate with $40-80 \%$ (b/v) saturation value (Scopes, 1994). After being precipitated overnight at $4{ }^{\circ} \mathrm{C}$, the enzyme then centrifuged at $10000 \times g$ for $15 \mathrm{~min}$. The obtained pellet was then dissolved in $0.1 \mathrm{M}$ citrate buffer $\mathrm{pH} 5$ and the dialysis process was carried out using 15 $\mathrm{mm}$ (diameter) dialysis bag (Sigma D0405). The precipitated enzyme was dissolved in $1 \mathrm{~mL}$ citrate buffer $50 \mathrm{mM} \mathrm{pH} \mathrm{5.0.} \mathrm{The} \mathrm{enzyme} \mathrm{solution} \mathrm{was} \mathrm{then} \mathrm{dialyzed}$ using dialysis bag with $12.5 \mathrm{mM}$ citrate buffer, and stirred using a magnetic stirrer at $4{ }^{\circ} \mathrm{C}$. The dialysis process was carried out overnight and $12.5 \mathrm{mM}$ citrate buffer was replaced with new buffer solution after 3 and $7 \mathrm{~h}$ of incubation.

Characterization of the precipitated enzyme was conducted based on $\mathrm{pH}$ and temperature treatments. The buffers $\mathrm{pH}$ used for characterization were $0.1 \mathrm{M}$ citrate buffer for $\mathrm{pH}$ range of 4.0-6.0, $0.1 \mathrm{M}$ phosphate buffer for $\mathrm{pH}$ range of $7.0-8.0$ and $0.1 \mathrm{M}$ glycine- $\mathrm{NaOH}$ buffer for $\mathrm{pH}$ range of 9.0-10.0. Meanwhile the optimum temperature was determined at temperature range of 20$90{ }^{\circ} \mathrm{C}$ with interval of $10{ }^{\circ} \mathrm{C}$ for every treatment (Sakr et al., 2013).

\section{Protein concentration measurement}

Protein concentration was measured using the method of Bradford (1976). A total of $2.5 \mathrm{~mL}$ Bradford reagent was mixed with $50 \mu \mathrm{L}$ crude extract enzyme and the suspension was homogenized using vortex then incubated for $10 \mathrm{~min}$. The absorbance value was measured using spectrophotometer at $595 \mathrm{~nm}$ wavelength.

\section{In planta inhibition assay of B. thuringiensis SGT3g against $\boldsymbol{D}$. dadantii}

This assay was conducted using hybrid orchid Phalaenopsis ekanagasaki provided from Bogor Botanical Garden, Indonesia. The orchid leaves were smeared with $3 \mathrm{~mL} B$. thuringiensis SGT3g culture of $10^{8}-10^{9} \mathrm{CFU} / \mathrm{mL}$ using a sterile brush. After the surface of leaves dried, each leaf sample was covered using a plastic bag and they were incubated for $24 \mathrm{~h}$. Then the leaves were stabbed using a sterile needle for 10 times. A total of $5 \mu \mathrm{L}$ D. dadantii $\left(10^{8}-10^{9} \mathrm{CFU} / \mathrm{mL}\right)$ was flooded onto each injection spot which was the Treatment I or the not coculture method. Treatment II was a mix culture (coculture) of $B$. thuringiensis SGT3g $\left(10^{8}-10^{9} \mathrm{CFU} / \mathrm{mL}\right)$ with D. dadantii $\left(10^{8}-10^{9} \mathrm{CFU} / \mathrm{mL}\right)$, a total of $3 \mathrm{~mL}$ mix culture was dripped onto each injection spot. The positive control of the assay is $D$. dadantii culture, while the negative control is $B$. thuringiensis SGT3g culture. After inoculation, the plants were covered using a plastic bag and incubated overnight. The occurrence of the disease symptoms (the number of spots with symptoms divided with total inoculation spots) and the development of 
disease symptoms (the diameter of the symptoms) were observed.

Twenty hours after inoculation of the pathogen, the samples of orchid leaves, positive control leaves, and treatment leaves were cut, macerated, and serially diluted. The dilution results were spread on LA plate which was added with $0.5 \%$ crystal violet and $25 \mathrm{ppm}$ ampicillin. $D$. dadantii colony was counted after $24 \mathrm{~h}$ incubation.

\section{RESULTS}

\section{Activity of B. thuringiensis SGT3g AHL-lactonase crude enzyme}

Activity of AHL-lactonase crude enzyme was detected in the supernatant and cell pellet extract (Table 1). This activity was indicated by the formation of non-purple zone around the paper disc. The results showed that the intracellular enzyme had the highest activity index of nonpurple zone formation than that of the extracellular enzyme.

Table 1: Crude extracts enzyme activity of $B$. thuringiensis SGT3g AHL-lactonase indicated by nonpurple zone formation of $C$. violaceum bacterial colony.

\begin{tabular}{lc}
\hline Enzyme Source & Non-purple Zone $(\mathrm{mm})$ \\
\hline Supernatant & $7.25 \pm$ SE 0.265 \\
Pellet & $10 \pm$ SE 0 \\
\hline
\end{tabular}

(a)

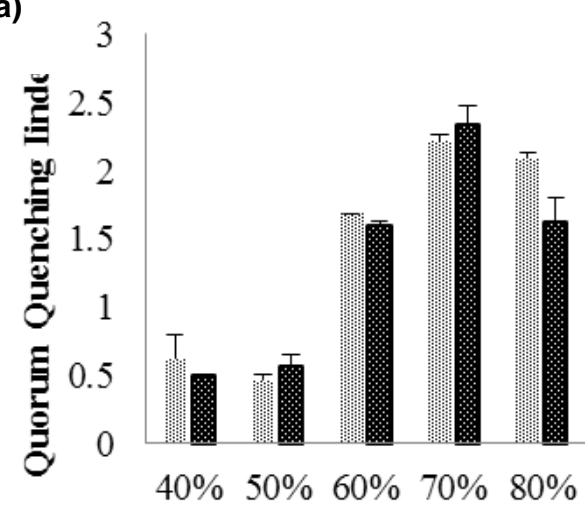

Ammonium Sulphate Concentration
Characteristics of precipitated AHL-lactonase of $B$. thuringiensis SGT3g

The data of protein precipitation showed that the highest precipitated protein concentration was at $70 \%(\mathrm{w} / \mathrm{v})$ ammonium sulphate (Figure 1). The data of quorum quenching index indicated that salting-out of $\mathrm{AHL}$ lactonase was occurred at $70 \%(\mathrm{w} / \mathrm{v})$ ammonium sulphate (Figure 2a). The quorum quenching index of the precipitated extracellular enzyme was higher than that of the intracellular enzyme (Figure 2b), so that the extracellular enzyme was used for further characterization.

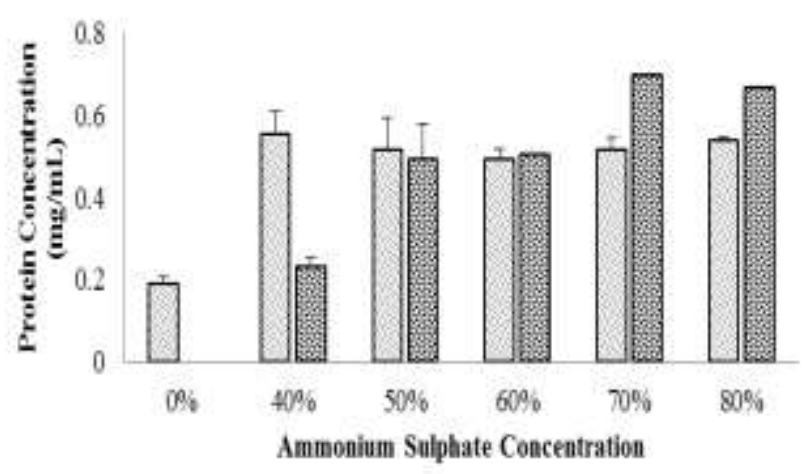

अ: Supernatant;

Figure 1: Protein concentration of the crude extract enzyme precipitated using ammonium sulphate.

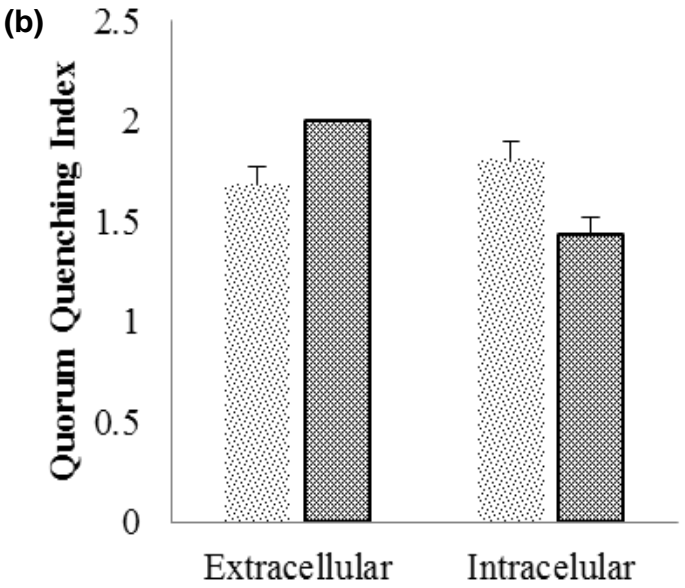

Figure 2: a, Quorum quenching index of $B$. thuringiensis SGT3g AHL-lactonase crude extract (III, supernatant; precipitated protein) and b, comparison of quorum quenching index between intracellular and extracellular enzymes ( $\$$, supernatant; | precipitated protein).

The activity and stability of extracellular AHLlactonase produced by $B$. thuringiensis SGT3g was characterized based on $\mathrm{pH}$ and temperature treatments. The results indicated that the enzyme had good stability in a wide range of $\mathrm{pH}$ and temperatures (Figure 3). However the optimum $\mathrm{pH}$ for the activity of the $\mathrm{AHL}$-lactonase was at $\mathrm{pH} 5$ and 6 indicated by the highest value of the quorum quenching index relative (Figure $3 a$ ). The enzyme also had good stability to the temperature treatments of $40-90{ }^{\circ} \mathrm{C}$ for $30 \mathrm{~min}$ indicated by the 
relatively low decreasing of the quorum quenching index relative values (Figure $3 \mathrm{~b}$ ). The activity of dialyzed AHLlactonase was higher than those of precipitated enzyme

(a)

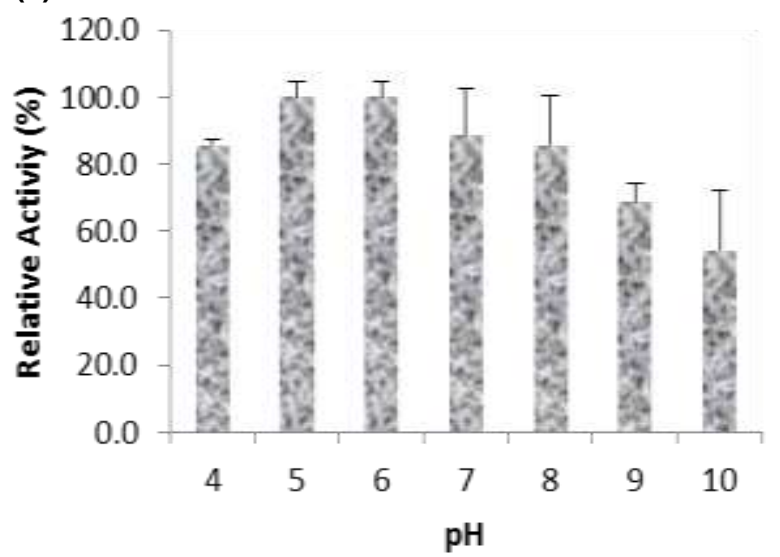

and crude extract enzyme, while the protein concentration of dialyzed enzyme was lower than that of the precipitated enzyme (Table 2).

(b)

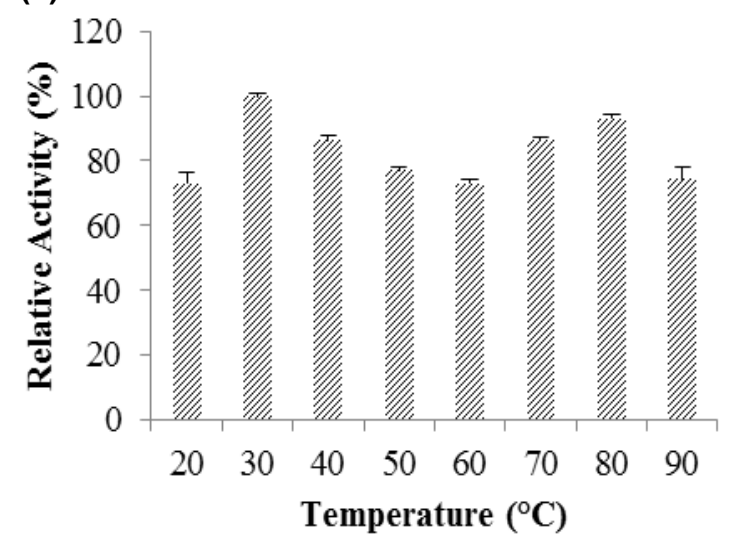

Figure 3: Relative activity of $\mathrm{AHL}$-lactonase at a, various $\mathrm{pH}$ and $\mathrm{b}$, temperature treatments.

Table 2: Relative activity of $B$. thuringiensis SGT3g AHL-lactonase during precipitation process.

\begin{tabular}{lccccc}
\hline $\begin{array}{l}\text { Precipitaion } \\
\text { Steps }\end{array}$ & Volume $(\mathrm{mL})$ & $\begin{array}{c}\text { Quorum } \\
\text { Quenching Index }\end{array}$ & $\begin{array}{c}\text { Protein Concentration } \\
(\mathrm{mg} / \mathrm{mL})\end{array}$ & $\begin{array}{c}\text { Total Protein } \\
(\mathrm{mg})\end{array}$ & $\begin{array}{c}\text { Relative Activity } \\
(\%)\end{array}$ \\
\hline Crude Extract & 200 & 0.812 & 0.583 & 116.6 & 100 \\
Precipitation & 2 & 0.969 & 0.916 & 1.832 & 103.6 \\
Dialysis & 2 & 1.406 & 0.3415 & 0.683 & 126.4 \\
\hline
\end{tabular}

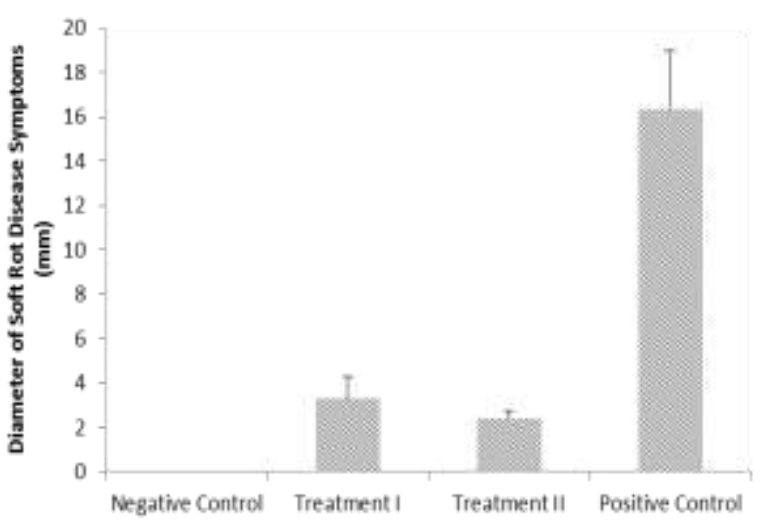

Figure 4: Diameter of soft rot disease symptoms on hybrid orchid Phalaenopsis leaves (Treatment II was coculture of $B$. thuringiensis SGT3g with $D$. dadantii).

\section{In planta inhibition assay of $B$. thuringiensis SGT3g against $\boldsymbol{D}$. dadantii}

The results showed that the rot symptom only occurred on positive control leaves after $24 \mathrm{~h}$ incubation. The leaves which inoculated with $B$. thuringiensis SGT3g showed less-severe rot symptom than that of the positive control. The rot symptom occurrence on leaves inoculated with $B$. thuringiensis SGT3g was $50 \%$, while on the positive control was $100 \%$ rot symptom occurrence. The diameter of rot symptom on leaves inoculated with $B$. thuringiensis SGT3g was $3.28 \mathrm{~mm}$, while on the positive control was $16.3 \mathrm{~mm}$ (Figure 4). However there was reduction of $D$. dadantii cell number on the leaves inoculated with $B$. thuringiensis SGT3g (Table 3). The co-culture treatment showed us the cell number of $D$. dadantii slightly higher than the not co-culture treatment (Treatment I). The soft rot symptoms on co-culture treatment showed lesser than not co-culture method (Figure 4).

Table 3: Comparison of $D$. dadantii cell number on the leaves of hybrid orchid Phalaenopsis.

\begin{tabular}{lc}
\hline $\begin{array}{l}\text { Inoculation } \\
\text { treatments }\end{array}$ & $\begin{array}{c}\text { Bacterial cell number of } D \text {. dadantii } \\
(\mathrm{CFU} / \mathrm{mL})\end{array}$ \\
\hline Inoculum & $1.12 \times 10^{9} \pm \mathrm{SE} 1.49 \times 10^{8}$ \\
Positive control & $1.01 \times 10^{9} \pm \mathrm{SE} 2.9 \times 10^{\prime}$ \\
Treatment I & $3.96 \times 10^{8} \pm \mathrm{SE} 3.41 \times 10^{7}$ \\
Treatment II* & $7.00 \times 10^{8} \pm \mathrm{SE} 1.75 \times 10^{8}$ \\
\hline${ }^{*}$ Treatment II was co-culture method
\end{tabular}




\section{DISCUSSION}

This study showed that $B$. thuringiensis SGT3g produced intracellular and excreted AHL-lactonase enzyme outside the cell as an extracellular enzyme. Some studies reported that $\mathrm{AHL}$-lactonase was produced by $B$. thuringiensis as an intracellular enzyme (Cao et al., 2012; Sakr et al., 2014). AHL-lactonase also produced in extracellular enzyme by Muricauda olaria which is not belongs to Bacillus group (Tang et al., 2015). In this study indicated that $B$. thuringiensis SGT3g produces both extracellular and intracellular AHL-lactonase. The $\mathrm{AHL}$ lactonase could hydrolyze $\mathrm{AHL}$ signal of $C$. violaceum indicated by the formation of non-purple zone around paper discs, because of the absence of violacein synthesis. The AHL signal is secreted outside the cell of C. violaceum for violacein pigment secretion process (McClean et al., 1997) which is responsible for the violet color in $C$. violaceum bacterial colony appearance. The other Gram negative bacterium $D$. dadantii also uses AHL signal for expression of virulence factor to degrade cell wall of plant.

The highest precipitated protein concentration of $B$. thuringiensis SGT3g crude extract enzyme of was at $70 \%$ $(w / v)$ ammonium sulphate with the highest quorum quenching index value of $\mathrm{AHL}$-lactonase. Most studies reported that $\mathrm{AHL}$-lactonases could be precipitated using ammonium sulphate in range of $30-80 \%$ saturation (Seo et al., 2011; Chen et al., 2010; Mukherjii and Prabhune, 2015). The recombinant AHL-lactonase of Bacillus sp. B546 expressed on Pichia pastoris was succesfully precipitated using $80 \%$ ammonium sulphate (Chen et al., 2010). Addition of ammonium sulphate up to $70 \%$ saturation precipitated $B$. thuringiensis SGT3g AHLlactonase optimally and increased the enzyme activity up to 1.2 times. However, the increasing of this enzyme activity is lower than that of Geobacillus caldoxylosilyticus YS-8 AHL-lactonase precipitated using 40-60\% ammonium sulphate saturation, which the increasing could reach up to 3.15 times (Seo et al., 2011).

The precipitated AHL-lactonase was purified through dialysis process to eliminate ammonium sulphate salt and other non-protein dissolved matters that their presence will inhibit the binding process of the substrates to the active site of AHL-lactonase, and eventually affecting the enzyme activity (Scopes, 1994). The total protein of AHLlactonase after dialysis was significantly decreased during dialysis process due to small proteins exited from the membrane. This study uses a $12.4 \mathrm{kDa}$ dialysis membrane, so that proteins smaller than that size will exit from the membrane, while those bigger proteins will remain in the membrane. The molecular weight of the $\mathrm{AHL}$ lactonase from $B$. thuringiensis $\mathrm{SGT3g}$ was 28.77 $\mathrm{kDa}$ based on SDS-PAGE analysis (Asmarani, 2014). Commonly the AHL Lactonase proteins of AiiA gene from Bacillus have molecular weight in the range of $28-31.5$ $\mathrm{kDa}$ (Chen et al., 2010; Cao et al., 2012). The AHL lactonase of $G$. caldoxylyticus YS-8 has molecular weight of $32 \mathrm{kDa}$ (Seo et al., 2011) and $\mathrm{AHL}$ lactonase of recombinant $M$. olearia was $31 \mathrm{kDa}$ (Tang et al., 2015).
The optimum activity of AHL-lactonase of $B$. thuringiensis SGT3g was at $\mathrm{pH} 5$ and 6 , its mean that the enzyme was active at acidic condition. Tinh et al. (2013) reported that the recombinant $\mathrm{AHL}$-lactonase from $B$. cereus had activity in $\mathrm{pH}$ range of $\mathrm{pH} 5-8$. The prediction of $\mathrm{AHL}$-lactonase protein produced by $B$. thuringiensis SGT3g was an acidic protein with isoelectric point at $\mathrm{pH}$ 4.7 (Asmarani, 2014). Wang et al. (2004) also reported that isoelectric point of $\mathrm{AHL}$-lactonase was at $\mathrm{pH} 4.17$. Although acidic condition can trigger re-lactonation to occur in opened AHL-ring (Dong et al., 2001; Chen et al., 2013; Ghani et al., 2014), the present study suggested that $\mathrm{AHL}$-lactonase of $B$. thuringiensis SGT3g had optimum activity at $\mathrm{pH} 5-6$. AHL-lactonase of Bacillus sp. Al96 had optimum activity at $\mathrm{pH} 8$, however it still had activity in $\mathrm{pH}$ range of 6-9 (Cao et al., 2012). While AHL lactonase of $B$. weihenstephanensis P65 had activity in $\mathrm{pH}$ range of $\mathrm{pH}$ 6-9 (Sakr et al., 2013).

The highest $\mathrm{AHL}$-lactonase activity was found at $30^{\circ} \mathrm{C}$ temperature treatment, however the enzyme still had activities after temperature treatments at $40-90{ }^{\circ} \mathrm{C}$ for 30 minutes incubation. This result indicated that the enzyme is resistant to high temperature. AHL lactonase of $B$. thuringiensis had optimum activity at $25-60^{\circ} \mathrm{C}$, and it was still able to show its activity after temperature treatment up to $70^{\circ} \mathrm{C}$ (Sakr et al., 2014).

Application of the AHL-lactonase of $B$. thuringiensis SGT3g could decrease soft rot disease symptoms caused by $D$. dadantii on $P$. ekanagasaki leaves (Figure 4). Previously, Dong et al. (2004) demonstrated the capability of $\mathrm{AHL}$-lactonase produced by $B$. thuringiensis to inhibit QS process of soft rot disease symptoms on a potato. Role of AHL-lactonase in inhibiting pathogenicity of the soft rot disease bacteria was described clearly using transgenic plants. Transgenic tobacco, A. konjac, and cabbage which expressed the inserted aiiA gene encoding AHL-lactonase were able to inhibit soft rot disease (Dong et al., 2001; Dong et al., 2002; Ban et al., 2009). However there was reduction of $D$. dadantii cell number on the leaves inoculated with $B$. thuringiensis SGT3g. This reduction cell number of $D$. dadantii might be due to limited nutrient availability and nutrient competition between $D$. dadantii and $B$. thuringiensis SGT3g on the leaves. Besides $B$. thuringiensis is well known as one of the successful environment-friendly biopesticides to control insect pests, based on the results, $B$. thuringiensis SGT3g also has potential application to be used as a biocontrol agent against phytopathogenic bacteria with the quorum quenching mechanism.

\section{ACKNOWLEDGEMENT}

This research was supported by a research grant of the Director General of Higher Education Republic of Indonesia.

\section{REFERENCES}

Afiah, T. S. N. (2011). Isolation and characterization of Acyl Homoserine Lactonase (AHL-lactonase) 
producing bacteria origin of agricultural land in Java. B.Sc. Thesis. Bogor Agricultural University, Indonesia.

Asmarani, A. (2014). Cloning and gene expression of Acyl Homoserine Lactone Lactonase from Bacillus cereus INT1c and Bacillus thuringiensis SGT3g. M.Sc. Thesis, Bogor Agricultural University, Indonesia.

Ban, H., Chai, X., Lin, Y., Zhou, Y., Peng, D., Zhou, Y., Zou, Y., Yu, Z. and Sun, M. (2009). Transgenic Amorphophallus konjac expressing synthesized acylhomoserine lactonase (aiiA) gene exhibit enhanced resistance to soft rot disease. Plant Cell Report 28, 1847-1855.

Barnard, A. M. L., Bowden, S. D., Burr, T., Coulthurst, S. J., Monson, R. E. and Salmond, G. P. C. (2007). Quorum sensing, virulence and secondary metabolite production in plant soft-rotting bacteria. Philosophical Transactions of the Royal Society B 362, 1165-1183.

Bradford, M. M. (1976). A rapid and sensitive method for the quantitation of microgram quantities of protein utilizing the principle of protein-dye binding. Analytical Biochemistry 72, 248-254.

Cao, Y., He, S., Zhou, Z., Zhang, M., Mao, W., Zhang, H. and Yao, B. (2012). Orally administered thermostable $\mathrm{N}$-acyl homoserine lactonase from Bacillus sp. strain Al96 attenuates Aeromonas hydrophyla inspection in Zebrafish. Applied and Environmental Microbiology 78, 1899-1908.

Chen, R., Zhou, Z., Cao, Y., Bai, Y. and Yao, B. (2010). High yield expression of an AHL-lactonase from Bacillus sp. B546 in Pichia pastoris and its application to reduce Aeromonas hydrophyla mortality in aquaculture. Microbial Cell Factories 39(9), 1-10.

Chen, F., Gao, Y., Chen, X., Yu, Z. and Li, X. (2013). Quorum quenching enzymes and their application in degrading signal molecules to block quorum sensingdependent infection. International Journal of Molecular Science 14, 17477-17500.

Choudhary, S. and Dannert, C. S. (2010). Application of quorum sensing in biotechnology. Applied Microbiology and Biotechnology 86, 1267-1279.

Czajkowski, R. and Jafra, S. (2009). Quenching of acylhomoserine lactone dependent quorum sensing by enzymatic disruption of signal molecules. Acta Biochimica Polonica 5, 1-16.

Dong, Y. H., Xu, J. L., Li, X. C. and Zhang, L. H. (2000). aiiA, a novel enzyme inactivates acyl-homoserinelactone quorum-sensing signal and attenuates the virulence of Erwinia carotovora. Proceedings of National Academy of Science 97(7), 3526-3531.

Dong, Y. H., Wang, L. H., Xu, J. L., Zhang, H. B., Zhang, X. F. and Zhang, L. H. (2001). Quenching quorum-sensing-dependent bacterial infection by an $\mathrm{N}$-acyl homoserine lactonase. Nature 411, 813-817.

Dong, Y. H., Gusti A. R., Zhang, Q., Xu, J. L., and Zhang, L. H. (2002). Identification of quorumquenching $\mathrm{N}$-acyl homoserine lactones from Bacillus species. Applied and Environmental Microbiology 68, 1754-1759

Dong, Y. H., Zhang, X. F., Xu, J. L. and Zhang, L. H. (2004). Insecticidal Bacillus thuringiensis silences
Erwinia carotovora virulence by a new form of microbial antagonism, signal interference. Applied and Environmental of Microbiology 70(2), 954-960.

Dong, Y. H., Wang, L. H. and Zhang, L. H. (2007). Quorum-quenching microbial infections: mechanisms and implications. Philosophical Transactions of the Royal Society B 362, 1201-1211.

Fitriyah, D., Wahyudi, A. T. and Rusmana, I. (2014). Characterization of bacteria producing acyl homoserine lactone (AHL) lactonase from agricultural lands. Advance in Environmental Biology 9(8), 140148.

Ghani, N. A., Norizan, S. N. M., Chan, X. Y., Yin, W. F. and Chan, K. G. (2014). Labrenzia sp. BM1: A quorum quenching bacterium that degrades $N$-acyl homoserine lactones via lactonase activity. Sensors 14, 11760-11769.

Kalia, V. C., Kumar, P., Pandian, S. K. T. and Sharma, P. (2015). Biofouling control by quorum quenching. In: Springer Handbook of Marine Biotechnology, Kim, S. K. (eds.). Springer-Verlag Berlin Heidelberg, India. pp. 431-440.

Kumar, P., Patel, S. K., Lee, J. K. and Kalia, V. C. (2013). Extending the limits of Bacillus for novel biotechnological applications. Biotechnology Advances 31(8), 1543-1561.

McClean, K. H., Winson, M. K., Fish, L., Taylor, A., Chhabra, S. R., Camara, M., Daykin, M., Lamb, J. H., Swift, S., Bycroft, B. W., Stewart, G. S. A. B. and Williams, P. (1997). Quorum sensing and Chormobacterium violaceum: Exploitation of violacein production and inhibition for the detection of $\mathrm{N}$ acylhomoserine lactones. Microbiology 143, 37033711.

McMillan, R. T., Palmateer, A. and Vendrame, W. (2007). Effect of rouging on Erwinia soft rot in commercial production with two Phalaenopsis plants per pot. Proceedings of The Florida State Horticultural Society 120, 3553-355.

Muharram, A., Indrasti, R. and Hanudin. (2012). Occurrence of Dickeya dadantii the causal agent of bacterial soft rot on orchids in Dki Jakarta and west Java Indonesia. Crop Environmental 3(1-2), 37-44.

Mukherji, R. and Prabhune, A. (2015). Enzyme purification and kinetic characterization of $\mathrm{AHL}$ lactonase from Bacillus sp. RM1 a novel and potent quorum quencher isolated from Fenugreek root nodule rhizosphere. International Journal of Current Microbiology and Applied Science 4(1), 909-924.

Park, S. Y., Lee, S. J., Oh, T. K., Oh, J. W., Koo, B. T., Yum, D. Y. and Lee, J. K. (2003). AhID, an Nacylhomoserine lactonase in Arthrobacter sp., and predicted homologues in other bacteria. Microbiology 149, 1541-1550.

Park, S. Y., Hwang, B. J., Shin, M. H., Kim, J. A., Kim, H. K. and Lee, J. K. (2006). N-acylhomoserine lactonase-producing Rhodococcus spp. with different AHL-degrading activities. FEMS Microbiology Letter 261, 102-108. 
Sakr, M. M., Aboshanab, K. M. A., Aboulwafa, M. M. and Hassouna, N. A. H. (2013). Characterization and complete sequence of lactonase enzyme from Bacillus weihenstephanensis isolate P65 with potential activity against acyl homoserine lactone signal molecules. Biomed Research International 1-10.

Sakr, M. M., Aboulwafa, M. M., Aboshanab, K. M. A. and Hassouna, N. A. H. (2014). Screening and preliminary characterization of quorum quenching activities of soil Bacillus isolates against acyl homoserine lactose of clinically isolate Pseudomonas aeruginosa. Malaysian Journal of Microbiology 10(2), 80-91.

Samson, R., Legendre, J. B., Christen, R., Fischer-Le Saux, M., Achouk, W. and Gardan, L. (2005). Transfer of Pectobacterium chrysanthemi (Burkholder et al., 1953) Brenner et al., 1973 and Brenneria paradisiaca to the genus Dickeya gen.. nov. as Dickeya chrysanthemi comb. nov. and Dickeya paradisiaca comb. nov. and delineation of four novel species, Dickeya dadantii sp. nov., Dickeya dianthicola sp. nov., Dickeya dieffenbachiae sp. nov. and Dickeya zeae sp. nov. International Journal of Systematic Evolutionary Microbiology 55, 1415-1427.

Scopes, R. K. (1994). Protein purification, principles and practice. $3^{\text {rd }}$ Edition. Springer-Verlag, New York. pp. 76-85 DOI: 10.1007/978-1-4757-2333-5.

Seo, M. J., Lee, B. S., Pyun, Y. R. and Park, H. (2011). Isolation and characterization of $\mathrm{N}$-acylhomoserine lactonase from thermophilic bacterium, Geobacillus caldoxylosilyticus YS-8. Bioscience Biotechnology and Biochemistry 75(9), 1-7.

Tang, K., Su, Y., Brackman, G., Cui, F., Zhang, Y., Shi, X., Coenye, T. and Zhang, X. H. (2015). MomL, a novel marine-derived $\mathrm{N}$-acyl homoserine lactonase from Muricauda olearia. Applied Environmental Microbiology 81, 774-782.

Tinh, N. T. N., Dung, N. V., Trung, C. T. and Thuy, V. T. (2013). In vitro characterization of a recombinant AHLlactonase from Bacillus cereus isolated from a striped catfish (Pangasianodon hypophthalmus) pond. Indian Journal of Microbiology 53(4), 485-487.

Wang, L. H., Weng, L. X., Dong, Y. H. and Zhang, L. H. (2004). Specificity and enzyme kinetics of the quorum quenching $N$-acyl homoserine lactone lactonase (AHL lactonase). Journal of Biological Chemistry 279, 13645-13651. 